\title{
The comparative study of advertising American presidency election campaign for both "Barack Obama"\& "Donald Trump "via advertising animation film with multimedia
}

\author{
Dina Ali Mohamed El-Besomey \\ PhD, The lecturer at Advertisement \& print \& Publication department/ Applied \\ Faculty/ Benha University/Egypt
}

Abstract

The role of advertising animation film as a political motivate in the contemporary reality strategy through multimedia in the research scale of universal unilateral force" America". and this reflection on the animation industry, which made the US authorities and capital owners as a political motivate towards political trends and political changes within and outside America worldwide , And this impact and reflection of our country Egypt and monitoring the effects and results of modern political changes in the contemporary Egyptian reality, and the need to presence of an national Egyptian defensing resistant to Western ideologies, especially the American ideology, which push the changes towards her interests and her advantages as well as the need for writing the history of our contemporary reality by Ourselves via all multimedia forms until they are not forging for the facts or the history with different ideology of the good Egyptian thought. Referring to the futurology, which was concentered with it by the century . As "Dr./ salah Qunsoua "pointed at introduction Book, entitled" the clash of Civilizations" Composed by: Samuil Hentgton - In response to what the current events causes in the world, like problems and questions, do not find their solutions, or responses in previous models, samples, tribes, familiar and accepted theories until recently. As the contemporary world status, which America \& Western Europe present the motivate of what facts happen and destroy the theories stabilized from the analysis of an interpretation.

Keywords: Advertisement -Animation-multimedia -Advertising American presidency election campaign, - the USA president-"Barack Obama"- "Donald Trump "- the Simpsons- propaganda- Video clip entitled "He's Barack Obama He's Come to Save the Day"-advertising animation film"Donald Trump will destroy America".

\section{Introduction}

The importance of research 
As this is a comparative and analyzing study of advertising animation film for both "Barack Obama"\& "Donald Trump" for their advertising campaign of American presidency election via multimedia. And what was written on the article in the Online Shorouk magazine, that: "The world leaders have to watch" Tom and Jerry, "and" Pink Tiger "and the series of animation" Simpson ", which has been predicted for 16 years with being Trump the president of America! So I'll compare and analysis the political projections on animation cadres in both: animation video clip entitled" He's BARACK OBAMA... He's come to save the day", and series animation "Simpson".

\section{The aim of research}

To get the results of advertising campaign of American presidency election for both "Barack Obama"\& "Donald Trump" via advertising animation film with multimedia. As both of them win in American presidency election. But there was different American public opinion. As there was cheerful delight with "Obama". There was opinions that America is going crazy when "Dounald" win in American presidency election. So I'll compare and analysis the political projections on animation cadres in both: animation video clip entitled" He's BARACK OBAMA... He's come to save the day", and series animation "Simpson". Because they emphasis this contemporary political reality.

\section{The research problems}

1) What is The role of "Cultivation Theory" in advertising animation film via multimedia?

2) Are there state symbols in the animation film as a political motivate in contemporary reality strategy?

3) What is the Political projections on advertising animation cadres as the animation series "Simpson"?

4) Why The Arab presidents and judgments especially should be see everything In the future broadcasting in the United States from Hollywood movies and also animations, The series of animation "Simpson" is as a political motivate in contemporary reality strategy?

5) What is the political projections via animation cadres in the animation series "Simpson"?

6) Analyzing The advertising Video clip of nominating Donald Trump for the presidency entitled "Donald Trump will destroy America".

7) Are there is emergence and development of advertising animation film as a political motivate in the management of disaster and crises?

8) What does it mean the emergence of state symbols in the American animation film as a political motivate in the contemporary reality strategy? 
9) What does it mean The Expressing about the USA presidential headquarters, "the White House"?

10) How many facts are expressing about American presidential elections in animation film? 11- Are the National Security Agency (NSA) is Spying on American citizens the reality or just imagination in animation film?

11) What is really about the American War on Afghanistan and Iraq?

12) What The New facts about the deleted episode of the Simpsons series entitled "Trump and Obama and Dash"?

13) Analyzing and comparing between the Advertising animation Video clip entitled "He's Barack Obama.. He's come to Save the Day", and The advertising Video clip of nominating Donald Trump for the presidency entitled "Donald Trump will destroy America". And what the real American impression of both presidents," Obama" and" Trump"and how both of the Advertising animation Video clips succeed in expressing that?

14) Time limits: 2000- until now 2021

15) Spatial borders: America \& Egypt and other Arab countries.

\section{Introduction}

This research is divided to several axes about the role the animation film as a political motivate in contemporary reality strategy, as the following:

The first axis: the role of "Cultivation Theory" in advertising animation film via multimedia

The second axis: The emergence of state symbols in the animation film as a political motivate in contemporary reality strategy

Political projections on cartoons in the animation series "Simpson"

Political projections on advertising animation cadres

The third axis Political projections on advertising animation cadres

- The Arab presidents and judgments especially appear to be forced In the future to see everything broadcasting in the United States from Hollywood movies and also animations, because they offer an up dative picture of what happens in the United States, and in the world in The near future?

The forth axis : Political projections on cadres in the animation series "the Simpsons" 
- The series of animation "Simpson" as a political motivate in contemporary reality strategy

- Monitoring the political projections via animation cadres in the animation series "Simpson"

- The advertising Video clip lyric of nominating Donald Trump for the presidency entitled "Donald Trump will destroy America"

The fifth axis: The emergence and development of advertising animation film as a political motivate in the management of disaster and crises

The emergence of state symbols in the American animation film as a political motivate in the contemporary reality strategy

The Expressing about the USA presidential headquarters, "the White House" and how to make decision in animation film as a political motivate in contemporary reality strategy

The sixth axis: Expressing about American presidential elections in animation film as a political motivate

The seventh axis :the Expressing about presidential elections, cheating methods and manipulation

The Expressing about Spying the National Security Agency (NSA) on American citizens in animation film as a political motivate

The eighth axis :The American War on Afghanistan and Iraq

The New is the deleted episode of the Simpsons series entitled "Trump and Obama and Dash"

The ninth axis: Video clip entitled He's Barack Obama He's Come to Save the Day

The Video clip lyric entitled "He's Barack Obama .. He's Come to Save the Day".

The first axis: the role of "Cultivation Theory" in advertising animation film via multimedia

It is appeared the role of "Cultivation Theory" in advertising animation film via multimedia . as Cultivation Theory depends on project cultural indicators, which searches in three following elements: the media production, the images beliefs, ideas and symbols introduced in the media content, and the relationship between receiving the cinema messages and audience behavior.as Cultivation analysis differ between three levels heavy receiver average receiver, little receiver

So Multimedia role in forming mental images. The media for many people are the main source of the formation of public opinion and therefore the world, which is 
lived by many people- according to "Lipman"(1922) and" adlman "(1988)- is a reality that is formed based on the interpretation of news .as"Lipman" has called " A counterfeit environment", and told "the media form the image of the world in our minds, and in the different areas of most important of it : the image of foreign countries, the image of the peoples and certain groups, the image of certain issues, the image of candidates in the elections, and the formation of expectations on certain events."

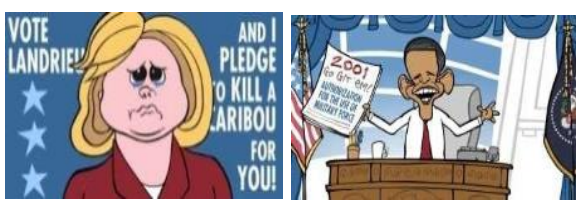

Figure (1) explains several cadres from the film " The Year In Crazy"", production: Mark Fiore Industries, Inc.year: 2014, Voice of Characterizations: Ray Lin, Stephanie Riggio, John Taylor

The second axis: The emergence of state symbols in the animation film as a political motivate in contemporary reality strategy

- Political projections on advertising animation cadres

When dimensions, objectives and political projections disappear from animation art. It shows The dangerous of advertising animation film, which directly affects the small kid mentality, which is a fertile soil to grow many ideas, which many use it widely in political and intellectual areas, and also many organizations and intellectual bodies use it to broadcast many its deadly propaganda Scenes via attractive scenes to get attention of many viewers towards them.

As the article in the Online Shorouk magazine, entitled "The world leaders have to watch" Tom and Jerry, "and" Pink Tiger "and the series of animation" Simpson ", which

has been predicted for 16 years with being Trump the president of America! So I'll compare and analysis the political projections on animation cadres in both: animation video clip entitled" He's BARACK OBAMA... He's come to save the day", and series animation "Simpson".

- Political projections on cartoons in the animation series "Simpson"

In this regard, the researcher deals with this series particularly because its future expectations motivate the contemporary political reality through two axes: first axis as a political motivate in the contemporary strategy, and the second axis: monitoring political projections via the series cadres.

The third axis Political projections on advertising animation cadres

- The Arab presidents and judgments especially appear to be forced In the future to 
see everything broadcasting in the United States from Hollywood movies and also animations, because they offer an up dative picture of what happens in the United States, and in the world in The near future?

The forth axis : Political projections on cadres in the animation series "the Simpsons"

- The series of animation "Simpson" as a political motivate in contemporary reality strategy

As for the Simpson family, "'The Samsons"called in the arabic version""omer Shamshons", "The character of "Simpson Jay Homer" and famed by" Homer" is a fake character and the hero of the animation series of the Simpson family, the series subject that Homer family-with the strange yellow to attract attention- consists of Homer,the father and his wife"marge,and three kids: Bart\& lisa\& Maggie. He was working in The nuclear power station "Serenfield" and Homer embodies the American moderate class. acting his voice:" Dan Castellaneta".For the first time on television, he appears with the rest of his family, in a short film entitled "Happy night" on April 19, 1987, the character of "Homer"is designed by Paintsit, "Matt Groening" while he is waiting in James L. Brokks'office hall "After its appearance for three seasons on Tracey Uliman channel, then Fox channels network get the right of publication this series to that chain and presented its first episode on 17 December 1989. Fox campany has owned the official sponsor of "The Simpsons" seriesUntil year 2082.

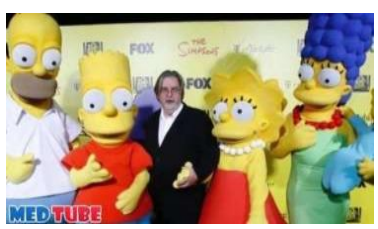

Figure No. (2) illustrates the image " Matt Groening With puppets of cartoon Simpson character,"

- Monitoring the political projections via animation cadres in the animation series "Simpson"

The American elected President- Trump has appeared in several episodes as a famous financial character but further appeared in the 30th episode of his candidacy for the United States presidency in the animation series" Simpson "entitled:" Bar to The Future "on 17 March 2000 and I have seen the episode which related with his campaign, the strange thing is that the scenario of Trump entry to the conference hall is match $100 \%$ with his entry into the cartoon series " The Simpsons ". All the scenes appeared in this cartoon episode before several years it has been embodied on the reality with the accurate details, like the clothes, the presence location ,the surrounding characters, his movements and the speech he said. 
And we understand that those who control the United States from a particular place are planning events for many years before they occur - before the War of Iraq, Afghanistan and the financial crisis, and before the presence of smart phones, especially before the digital revolution.

Where the father "Homer" goes to the future to find the conference "Donald Trump" and he is presenting to the USA president in the press. After The country will lose her mind. As America will fall down in the rest of the rich trump family, which control America and the the world too. There is a little who remembered this laughing and reliable episode that remembered by Sky News and broadcasted the comic episode that was given to the episode writer, a great fame since the date of Donald Trump won the presidency.
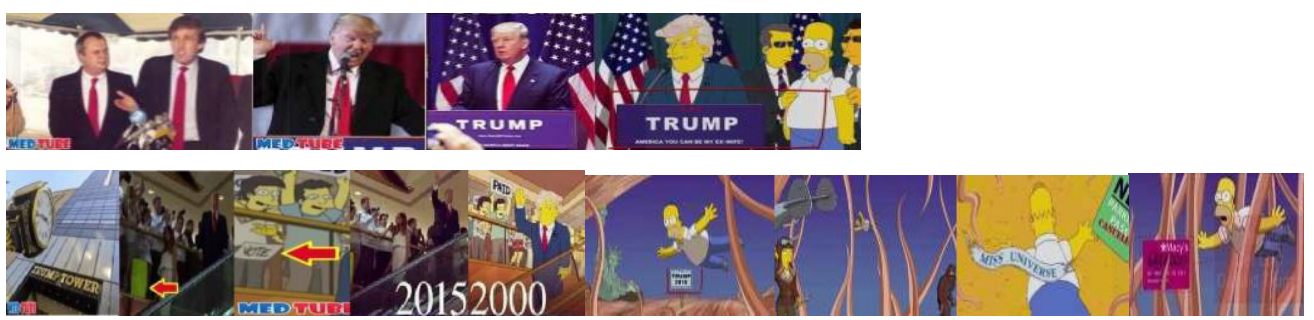

Figure No. (3) explains several cadres from one of the Simpson Family episodes in 2000 predicted that Trump becomes the president and conformed with the scene in the contemporary reality after several years when Trump was already nominated to preside the United States of America In the late 1980s, Trump was recently nominated in 2016 and the usual tray scene in the Trump Tower, and finally after he become the President of the United States and the fears about his shocking statements.

Note that: it is Written "Trump :America you can be my ex-wife!"

In July 2015, Donald Trump is nominated for the presidency of the United States of America on the Republican Party - but no one get interested because no one believed, he

would win and he won on 2 November 2016. "Dan Grini" is one of the writers of Simpson episodes "the Serial hasn't no predictions and the author is not the actual ruler of the world and everything is trying from the series' team work to renew and keeping away from repetitions in his more than 500eposide and display political and humanitarian issues in a comedy way. The delivery of Trump presidential councils was warning to the USA .This vision is matching with that the Americans will become mad. "As in 2015 and after Trump's candidacy for the US presidential elections, a short sarcastic clip was issued:" Trump Tasting Voyage "as the clip shows Tramp goes down the electric staircase between a group of his supporters while one of them falls a sign . that is actually repeated at the beginning of 2016 during the Trump's elections Campaign, but the electric staircase scene is a famous 
scene in the Trump Tower. The clip shows the actual economic situation of the United States is now, and the very disastrous .

This is known that "The Simpson family series is "one of the most controversial series recently because her predication with future events before it occurred, like the events of September 11, the Arab Spring revolutions, the invention of the iPhone, smart clock, three- dimensional printers, and finally the victory of the American president" Donald Trump

Some think that The Simpsons series display many mysterious predictions in the world of politics, medicine and even physics and terrorism. And everything is dominant, everything is controlled in us, our minds and in our plants, and its discoveries and in natural disasters and tell us sometimes what they intend to do and the world in a semi-sling.

The advertising Video clip lyric of nominating Donald Trump for the presidency

entitled "Donald Trump will destroy America"

Narration

No way you give me idea you have freedom to give a choice You don't have no choice

You have owner they own you

Video clip lyrics

Elope nineteen you come to take control

You take my IP but you can break my sole

Elope nineteen you come to take control

You take my IP but you can break my sole

You know ebola we need you not at all

Narration

Perhaps they have much money

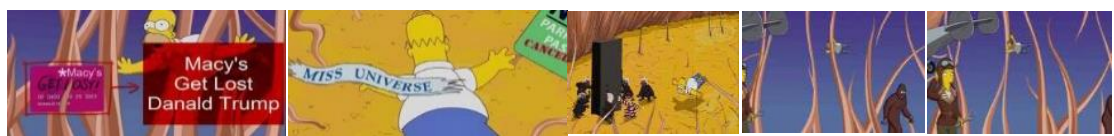




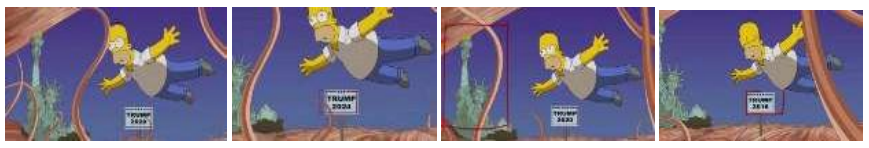

Figure No. (4) illustrates several cadres from the Simpsons series, this following years:" 2012-2016-2020-2024-2028

The fifth axis: The emergence and development of advertising animation film as a political motivate in the management of disaster and crises

The Simpsons series predict with Ebola virus. in the 1997 an episode displayed about Ebola virus without having a relationship with the story of the episode, where the mother is introduced a book for her patient's son carrying his cover the phrase" Virus Ebola "and shows a sleeper monkey. It knows that the monkeys pointed out the accusing fingers for a long time therefore being carried by the virus and the origin of its spread. When the series team workers were asked about this, their response was that the disease was known since 1976 and renewed its appearance in 2014. It was almost becoming a globally disease but it remained in West Africa.
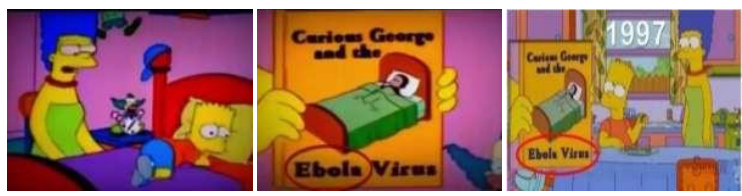

Figure No. (5) illustrates several cadres from the Simpsons series

In the rest of the episode, "Bart" is a failed music, while his sister Lisa was the first president of the United States - nodes here to Hillary Clinton - after the President Trump, who left the country in a bad financial position.as liza's dialogue :"We inherited a critical situation." When Lisa asked, her secretary - the president's Secretary of the United States - " Fan Hoten" for the financial situation, and he answered her : "we are bankrupt"".
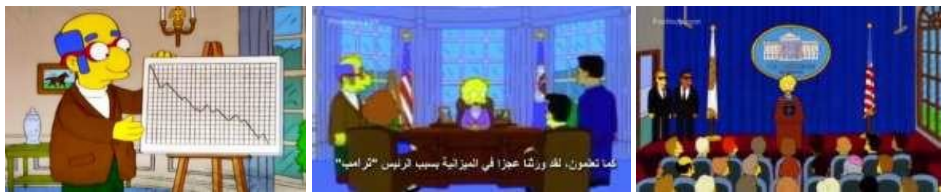

Figure No. (6) explains several cadres from one of the Simpsons episodes

The episode ends with Lisa's heroine the burden of the USA presidency after the failure of the trump's policy economically and also appears in another shot that Lisa friend -Mill House- - explained with a graph the unfortunate status that has been forced to take subsidies from China. 

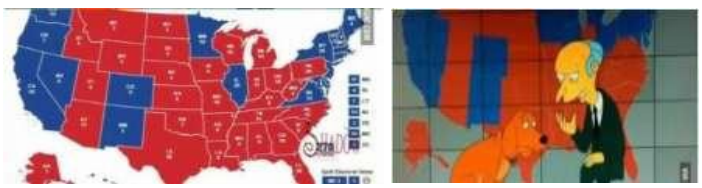

Figure No. (7) illustrates a cadre from one of the Simpsons episodes

And the absent reality of everyone that Trump has expressed its political ambition to reach the USA presidential chair in 1987, after one year the appearance of the first episodes of the series " The Simpsons", and announced his candidacy since October 1999, to enter the USA presidential race for the first time in 2000. Candidated by A small American reform party. Some political analysts surprised his shares by winning Trump the USA presidency, nominated by the Republic party. As he appeared in The Simpsons series since 17 years in the 84-year-old in 2033, and he has brought to America a Sufficient crisis and broken finances in external debt and in the dependency of Europe, China and their subsidies. Grape. This scenario comes in contrast to the trump election campaign in which he is promised a maximum economic residence and restoration of America.

- The emergence of state symbols in the American animation film as a political motivate in the contemporary reality strategy

- The Expressing about the USA presidential headquarters, "the White House" and how to make decision in animation film as a political motivate in contemporary reality strategy

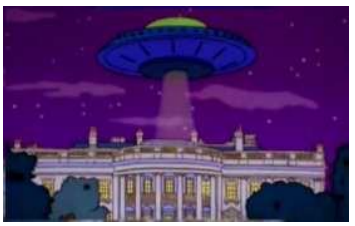

Figure No. (8) illustrates several cadre from the Simpsons series

The sixth axis :Expressing about American presidential elections in animation film as a political motivate

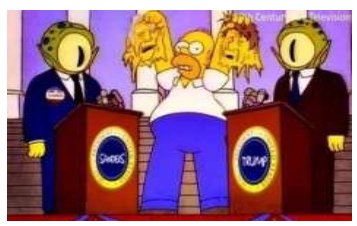

Figure No. (9) shows several cadre from the Simpsons series

The seventh axis :the Expressing about presidential elections, cheating methods and manipulation cheating voting machine: the Episode 4 in Part 28, "Homer" the Main character P voted for Obama but votes is wrongly gone for " Jen Markin" and after 4 years and during the USA electoral events occurred the same thing in 
Penslvania state that all The votes that were in favor of Obama went to his first rival "Med Trump Nei ".

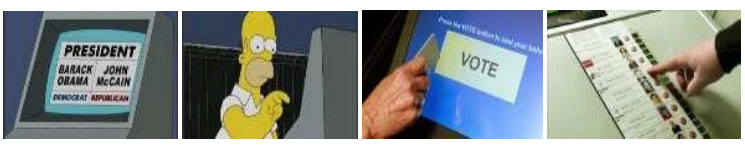

Figure No. (10) Explains several cadre from the Simpsons series

- The Expressing about Spying the National Security Agency (NSA) on American citizens in animation film as a political motivate

The scene of the Simpsons series in 2007"Liza and Marg" was hiding afraid of the government tring to save their city from destroying. So liza is trying to warn her relatives about their conversations, because the government is spying on their conversation and it is not away that this spy is included all citizens.
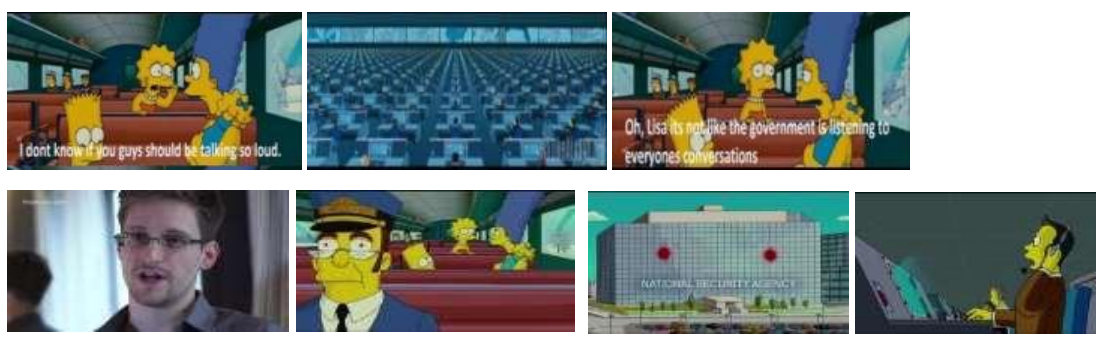

Figure No. (11) explains several cadres of the Simpsons series, at the top cadres illustrate the dialogue that the USA government monitors the telephone talks of her citzens, and below the cadres illustrate by the employee who was working on the USA National Security Agency and explains this fact

It is mentioned that the series broadcasted via Fox News, proven the truth of his expectations for the future, making some say that it's a thoughtful plan for the leakage of their plans in series and films .for two reasons, their huge numbers and the prohibition of communication between them except Hierarchy.

Also in Hollywood movies, which merged the reality into the computer graphic and optical illusion as in the " Terminator part II", "Judgment Day", in 1991 so some videos came online and on YouTube thought that the series team workers may be Illuminati. As The series "Simpsons" on the 20th century Fox television mention some political phrases as a United Nations debate, "system with any pay "I am high with capitalism".
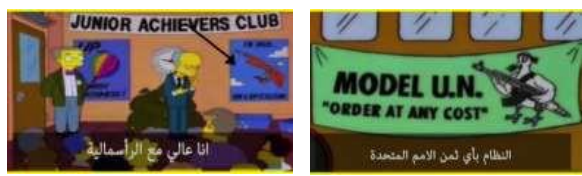

Figure No. (12) explains several cadres from the Simpsons series 
The eighth axis :The American War on Afghanistan and Iraq

The USA War was addressed in Afghanistan and Iraq . in one of the Simpsons series and volunteering in the US military. and what the american news agency told about the previous American president policy "Jorge bosh."

- The New is the deleted episode of the Simpsons series entitled "Trump and Obama and Dash"

In the special episode, which was displayed between 2004: 2008, "Trump" appears accompanied by a man from African assets called "Tommy". Tommy- which is similar to the Park Obama- speaks so afraid of something with Donald Trump. While Trump gives him two pieces of money category $\$ 100$, who is irritatingly and tremblingly in a scene that does not exceed 10 seconds .
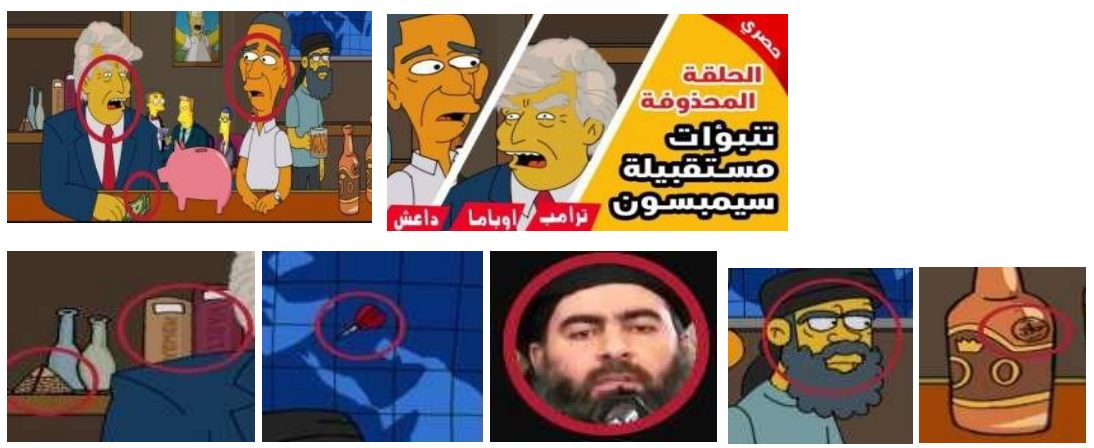

Figure 13 illustrates one of the scenes expressed a lot of hidden messages from a piggy bank - symbolizes that America may need in the future for China support- to the rest of the items in the background

- Drink bottle (wine) on the table, there is a small stamp with "Halal" in Arabic clearly !!

- The man in the background of the scene carries an Arab Islamic features the same as the dash's leader of Abu Bakr al- Baghdadi.

- It also appears in the background map for the Middle East and notes a red shooting arrow on the map and specifically on Syria or the recent dash's influence area

- On the shelve there is a small pyramid - one of the fishery symbols - in addition to two books with names of Arab countries suffer from dash's presence in its territory, they are "Libya" and "Yemen".

-There are some images in the background of the scene like "Homer in a hysterical case because of the frequent volatile money around him. And There is a picture of Liza behind the bars after being arrested.

The ninth axis: Video clip entitled "He's Barack Obama .. He's Come to Save the Day". 
Barack Obama is the supernatural Hero as Super Man, which will achieve the impossible for America at the internal and external level in its international relations and the video clip shows the supernatural capabilities of Barack Obama.
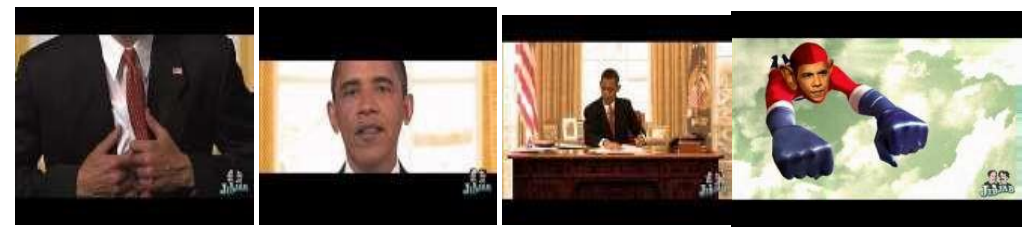

Figure No. (14) explains several cadres from Video clip entitled

The Video clip lyric entitled "He's Barack Obama .. He's Come to Save the Day".

When darkness had descended all across the land

Alone voice in the distance uttered Yes! We can!

He gave good speeches Never sweat

He was real good at the internets

He's Barack Obama He's come to save the day

He passed a major stimulus for the Bourgeois

Then said he'd half the deficit he he! Ha ha!

Stop unemployment! Market Dives!

Fix healthcare in his spare time

He's Barack Obama He's come to save the day

He'll use his superpowers to win in Iraq

Then kung fu chop the Taliban

Ka- chow ! ka - cha! Ka- chow ! ka - cha!

Our image in the world he'll mend Then make the Jews and Arabs friends!

He's Barack Obama He's come to save the day

Telephone is being called

Officer : sir, we got a situation Obama: piorates

He'll spend the dough! Write the checks !

Disregard the mounting debt! Stop the globe from getting warm!

Fuel your car with nuts and corn! Leap a building!

Run industry! Save a kitten from a tree! 
Fix the schools! Go to space!

Stop a train ! wrestle bears!

Smoke a butt! We don't care

Cuz you're Barack Obama You've come to save the day!

So just snap your fingers and fix the USA!

YA YA YA
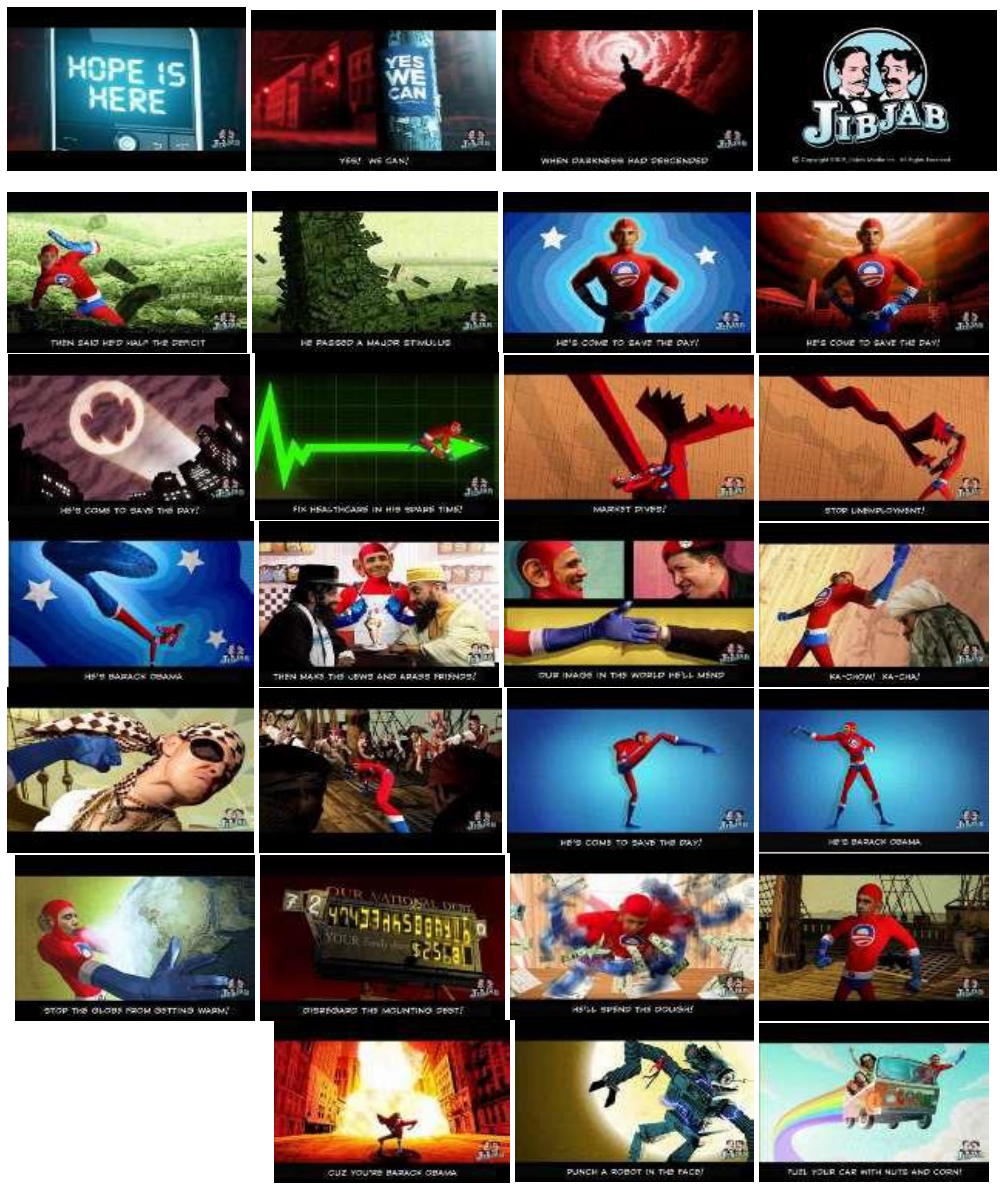

Figure No. (15) explains several cadres from Video clip entitled "He's Barack Obama .. He's Come to Save the Day".

\section{Conclusion}

By Analyzing and comparing between the Advertising animation Video clip entitled "He's Barack Obama.. He's come to Save the Day", and The advertising Video 
clip of nominating Donald Trump for the presidency entitled "Donald Trump will destroy America". And what the real American impression of both presidents," Obama"and" Trump"and both of the Advertising animation Video clips succeed in expressing how Obama will be loved by Americans as a superhero, and that what happened when he became the American president. And all the right fears of Trump and how Americans are going to crazy.

\section{Results\& Recommendations}

[1] The important role of "Cultivation Theory" in advertising animation film via multimedia

[2] The emergence of state symbols in the animation film as a political motivate in contemporary reality strategy

[3] There is Political projections on advertising animation cadres , as the animation series "Simpson"

[4] The Arab presidents and judgments especially should be see everything In the future broadcasting in the United States from Hollywood movies and also animations, because they offer an up dative picture of what happens in the United States, and in the world in The near future?

[5] The series of animation "Simpson" is as a political motivate in contemporary reality strategy

[6] Monitoring all the political projections via animation cadres in the animation series "Simpson"

[7] The future vision of The advertising Video clip of nominating Donald Trump for the presidency entitled "Donald Trump will destroy America"

[8] The emergence and development of advertising animation film as a political motivate in the management of disaster and crises

[9] The emergence of state symbols in the American animation film as a political motivate in the contemporary reality strategy

[10] The Expressing about the USA presidential headquarters ,"the White House" and how to make decision in animation film as a political motivate in contemporary reality strategy

[11] Expressing accurately about American presidential elections in animation film as a political motivate, as: cheating methods and manipulation

[12] The Expressing accurately about Spying the National Security Agency (NSA) on American citizens in animation film as a political motivate

[13] The cruel American War on Afghanistan and Iraq

[14] The New facts about the deleted episode of the Simpsons series entitled 


\section{"Trump and Obama and Dash"}

[15] Advertising animation Video clip entitled "He's Barack Obama.. He's Come to Save the Day", shows how Obama will be loved by Americans as a superhero, and that what happened when he became the American president.

Note. This research is introduced as worksheet to publish my post- PHD researches in EJMS (European Journal of Multidisciplinary Studies) and for the International Continuous Online Conference "Recent Ideas and Research", organized Online Platform at the venue of Revistia Headquarter, Revistia Publishing, 11 Portland Road, London, UK on 17-18 September 2021

\section{References}

[1] Charles Solomon, the history of animation,2nd ed.(new york:random house,1994.)

[2] Dina Ali Mohamed EL-Besomey,"The Expressing of the contemporary political reality in the animation film via multimedia (Analytical study)", an unpublished PHD theses, Animation Department / Higher Institute of Cinema / Academy of Arts ,2018

[3] El-khaber Dictionary of electronic encyclopedia Spokesome, Atlas Publishing House, Website: www.atlastic.com.

[4] Future Concepts, Eternal Law for International Interactions, Monthly Supplement issued with Periodic "Event Trends", Future Center for Advanced Research and Studies, Issue 10 May 2015, www. Future Center .ae .

[5] Hungeton. Samuel, clash of Civilizations, Re-Making Global System, Translation: Talaat El Shayeb, presented by:Talaat Qassawa, Egyptian Book House, Cairo, Second Edition, 1997, Original Post Date: 1996, Deposit in the Egyptian Books ,1997

[6] International Policy, quarterly scientific court, number two hundred, April 2015, Al Ahram Trading Printing, http: //www.siyassa.org.eg

[7] Kamel Telamani, Ambassador of America, Natural Color, Humanities, Egyptian General Authority for Book, Family Library,2012

[8] Karl f.cohen-forbidden animation :censored cartoons and blacklisted animator in America .mcfarland press, use(n.carolina) 1997.

[9] Mai Ibrahim Hamza, the image of the Arab cases in the political cartoons and its impact on the mental image of youth (comparative study between the Internet and printed newspapers), an unpublished Master theses, Faculty of Arts, Department of Communication and Information, Helwan University, September 2006. 
[10] Marwa Ahmed Youssef El Sherif, Employment of Animation and Multimedia Technology in the production of an entertaining educational site, an unpublished Master theses, Graphic department, Faculty of Fine Arts, Helwan University, 2011.

[11] Radwa Ammar" - Doctor's researcher in international relations and international organization at the Faculty of Economics and Political Science Cairo University "National Interest: How does the state manage their cooperative and strict interactions?"

[12] Strategic transformations on the international political map, International Policy Magazine Supplement, Number of two hundred, April 2015 ,Al Ahram Trading Printing, http://www.siyassa.org.eg

[13] Tarik Mohamed Faraj, mutual impact between politics and animation, an unpublished Master theses, Graphic department, Faculty of Fine Arts / Helwan University, 2012.

[14] The expressing of the contemporary political reality in the animation film via multimedia (Work Sheet),for DR./Dina Ali Mohamed EL-Besomey, the lecturer of advertisement \&print \&publication department/applied art faculty. A Brief of PhD Thesis Of cinema arts Philosophy Introduced to the International Conference of Higher Education Development: Global Variables and International Standards, Organized by Benha University 22-23 Jan 2019

[15] Trending Events, Academy Trends on the Future Center for Advanced Research and Studies, Issue 10 May 2015, www.FutureCenter.ae.

Websites

[1] http://www.echoroukonline.com/ara/articles/504012.html

[2] https://www.google.com.eg/search?newwindow=1\&safe=active\&q=\%D8\%A 3\%D9

[3] http://rebloggy.com/post/mine-atla-avatar-the-last-airbender-text-posts-icant-

[4] http://ar.wikipedia.org/wiki/\%D8\%A7\%D9\%84\%D9\%85\%D8\%AA\%D8\%A D\%D9

[5] http://www.sasapost.com/movies-about-making-movies/

[6] http://vb.movizland.com/t26568

[7] http://www.saidacity.net/news/187392/\%D8\%A7\%D9\%84\%D8\%B1\%D8\%A4\%D9 \%88\%D8\%B3

https://ar.wikipedia.org/wiki/\%D8\%AA\%D8\%B5\%D9\%88\%D9\%8A\%D8\%B1_\%D8 \%AB\%D9\%84 
[8] https://ar.wikipedia.org/wiki/\%D8\%AA\%D8\%B5\%D9\%88\%D9\%8A\%D8\%

[9] http://jolenelzlmimi.blogspot.com/2010/08/avatar-last-airbender.html

[10] https://ar.wikipedia.org/wiki/\%D8\%AD\%D8\%B1\%D8\%A8

[11] AlTahrirnewspaperOnlineDate7/4/2017,http://www.tahrirnews.com/pos/ 314612/\%D8\%ad\%D8\%B1\%D8\%

[12] Journal of the week Online on 28/3/2017,http: // www. Week. COM / MT 218112,

[13] ThenewspaperRosalyphusistOnlineon7/4/2017,http://www.rosaeveryday.c om/news $/ 132728 / \%$ D8\%A3\%D9\%81\%

[14] Journal of the Seventh Day Online http://www.youm7.com/story/2016/10/7/ 